\title{
Protecting the plain packaging consultation from tobacco industry interference
}

\author{
Julia Smith PhD, Kelley Lee DPhil
}

Competing interests:

None declared.

This article has been peer reviewed.

Correspondence to: Julia Smith, jhs6@sfu.ca

CMAJ 2016. DOI:10.1503 /cmaj.160791
$\mathrm{T}$

obacco products have been shown to lose some of their appeal when colours, images and brand names are removed from packaging. ${ }^{1}$ The tobacco industry, however, is well known for opposing plainpackaging initiatives. It has spread misinformation, commissioned junk science and sought to influence policy-makers through think tanks and other third parties. ${ }^{2}$ On Aug. 31, 2016, the Canadian government's public consultation on plain and standardized packaging for tobacco products, the first step toward implementing this effective public health measure, will close. The government must guard against tobacco industry interference during the consultation and the legislative process to follow.

During the mid-1990s, Canada was poised to become the first country to adopt plain packaging. Tobacco companies vociferously argued that the measure would violate Canada's obligations under international trade and intellectual property agreements. Internal industry documents, which became available years later, revealed a well-orchestrated campaign based on the "misrepresentation of international trade law." 3 The industry succeeded in creating enough fear of an expensive legal battle to make lawmakers back away.

When the Australian government took up plain packaging more recently, adopting legis-

\section{KEY POINTS}

- In May 2016, the Canadian government announced a public consultation on plain and standardized packaging for tobacco products, which closes on Aug. 31, 2016.

- When the Australian government introduced plain packaging in 2011, tobacco companies tried to use trade law, intellectual property rights and biased research by allied institutions to thwart the initiative.

- Troubling tactics are now being deployed in Canada, with individuals and organizations with known links to the tobacco industry speaking against plain packaging in the media.

- The Canadian government must require any individual or organization making a submission to the federal consultation to declare potential conflicts of interests, including funding sources, and must require that any claims made in submissions be substantiated by peer-reviewed evidence, with transparent methodologies, non-industry-linked data sources and clear funding declarations. lation in 2011, tobacco companies again tried to use trade law and intellectual property rights to thwart public health efforts. After these legal challenges failed, tobacco companies turned to disseminating misinformation through think tanks and other allies. For instance, British American Tobacco commissioned research by KPMG that suggested a rise in tobacco smuggling in Australia after the new policy was introduced. ${ }^{4}$ However, peer-reviewed research not funded by industry found that such studies had flawed methodologies and that plain packaging did not increase smuggling. ${ }^{5}$ Tobacco companies also claimed that plain packaging was ineffective, citing reports by Sinclair Davidson, ${ }^{6,7}$ a senior research fellow at the Institute of Public Affairs (Australia), a think tank that has admitted receiving tobacco industry funding in the past. ${ }^{8}$ Cancer Council Victoria described Davidson's reports as factually erroneous, heavily biased and lacking statistical significance. ${ }^{9}$

The industry has begun to deploy troubling tactics in Canada. One CBC article quoted Julian Morris of the Reason Foundation, a US think tank that received industry funding throughout the 1990s. ${ }^{10}$ Nondisclosure of funding sources means it is not possible to know whether the Reason Foundation still receives industry funding, but the quotation in the news article raises concerns about undeclared conflicts of interest. Morris questioned the effectiveness of plain packaging by referring to Davidson's questionable Australian research. Indeed, Davidson has been widely covered in the Canadian media making familiar (and independently disproven) claims about plain packaging that would seem to be supported by industry. ${ }^{11}$ The media fail, however, to mention critiques of his work or his industry ties.

Using similar arguments, the Canadian Convenience Stores Association produced a press release, which stated that plain packaging "will have unintended consequences for small business owners and Canadians, which will undermine tobacco cessation initiatives." ${ }^{12}$ It is notable that, at the time of writing, the website of 
this association listed the Canadian subsidiaries of British American Tobacco (Imperial Tobacco), Japan Tobacco International (JTIMacdonald) and Philip Morris (Rothmans, Bensons \& Hedges) as associate members, and the association's spokespersons have acknowledged funding from tobacco companies in the past. The position of the Canadian Convenience Stores Association mimics that of its Australian counterpart, the Alliance of Australian Retailers, which (according to leaked documents) was set up as a front group by Philip Morris to create the impression of a grassroots campaign against plain packaging. ${ }^{13}$

The Canadian media should remember their important role in challenging industry-affiliated sources regarding their conflicts of interest, and should guard against simply becoming vehicles for industry misinformation. Public health advocates must engage with the media to counter these spurious claims, critique weak research and share evidence regarding the strengths of public health measures such as plain packaging. The Canadian government must learn from the past and from international lessons. In particular, the government must require any individual or organization making a submission to the federal consultation to declare potential conflicts of interests, including funding sources, and must require that any claims made in submissions be substantiated by peer-reviewed evidence, with transparent methodologies, non-industry-linked data sources and clear funding declarations.

\section{References}

1. Moodie C, Stead M, Bauld L, et al. Plain tobacco packaging: a systematic review. London (UK): Public Health Research Consortium; 2012. Available: http://phrc.lshtm.ac.uk/papers/ PHRC_006_Final_Report.pdf (accessed 2016 Aug. 16).

2. Smith J, Thompson S, Lee K. The atlas network: a "strategic ally" of the tobacco industry. Int J Health Plann Manage 2016 Apr. 28 [Epub ahead of print].

3. Packaging phoney intellectual property claims. Ottawa: Physicians for a Smoke-Free Canada; 2009. Available: www.smoke-free .ca/plain-packaging/documents/2009/packagingphoneyipclaims -june2009-a4.pdf (accessed 2016 Aug. 16).
4. Illicit tobacco in Australia. London (UK): KPMG; 2014. Available: https://home.kpmg.com/uk/en/home/insights/2015/11/ illicit-tobacco-in-australia.html (accessed 2016 Aug. 16).

5. Scollo M, Bayly M, Wakefield M. Availability of illicit tobacco in small retail outlets before and after the implementation of Australian plain packaging legislation. Tob Control 2015;24:e45-51.

6. Davidson S, de Silva A. The plain truth about plain packaging: an econometric analysis of the Australian 2011 Tobacco Plain Packaging Act. Agenda J Policy Anal Reform 2014;21:27-43. Available: http://press.anu.edu.au/wp-content/ uploads/2014/11/The-Plain-Truth-about-Plain-Packaging-An -Econometric-Analysis-of-the-Australian-2011-Tobacco-Plain -Packaging-Act.pdf (accessed 2016 Aug. 16).

7. Davidson S, de Silva A. Stubbing out the evidence of tobacco plain packaging efficacy: an analysis of the Australian National Tobacco Plain Packaging Survey. Rochester (NY): Social Science Research Network; 2016. Available: http://papers.ssrn. com/sol3/papers.cfm?abstract_id=2780938 (accessed 2016 Aug. 16).

8. D'Cruz D. Give smokers some respect. The Australian [Surry Hills] 2002 Apr. 15:13. Available: www.abc.net.au/mediawatch/ transcripts/1014_respect.pdf (accessed 2016 Aug. 16).

9. Comments on "Davidson S, de Silva A. Stubbing out the evidence of tobacco plain packaging efficacy: an analysis of the Australian National Tobacco Plain Packaging Survey, Social Science Research Network." Melbourne (Australia): Cancer Council Victoria; 2016. Available: www.cancervic.org.au/ downloads/plainfacts/Davidson_working_paper_comments_3 June_2016.pdf (accessed 2016 Aug. 16).

10. Gollom M. Plain cigarette packaging a hit with anti-smoking advocates, but debate about whether it works continues. $C B C$ News 2016 June 1. Available: www.cbc.ca/news/health/plain -packaging-cigarettes-liberals-australia-1.3609015 (accessed 2016 Aug. 16)

11. Hannaford P. Mandating plain packaging on cigarettes doesn't work. National Post [Toronto] 2016 May 4. Available: http://news .nationalpost.com/full-comment/patrick-hannaford-mandating-plain -packaging-on-cigarettes-doesnt-work (accessed 2016 Aug. 16).

12. Retailers concerned plain packaging will undermine tobacco control measures [press release]. Oakville (ON): Canadian Convenience Stores Association; 2016 June 6. Available: www.theccsa .ca/content/retailers-concerned-plain-packaging-will-undermine -tobacco-control-measures (accessed 2016 Aug. 16).

13. Davies A. Big tobacco hired public relations firm to lobby government. Sydney Morning Herald 2010 Sept. 1. Available: www.smh .com.au/national/big-tobacco-hired-public-relations-firm-to-lobby -government-20100910-154yg.html (accessed 2016 Aug. 8).

Affiliation: Faculty of Health Sciences, Simon Fraser University, Burnaby, BC

Contributors: Julia Smith conducted research for the commentary. Both authors collaborated in the writing of the commentary, approved the final version for publication and agreed to act as guarantors for the work.

Funding: This work was supported by the National Cancer Institute, US National Institutes of Health, grant R01-CA091021. The contents of this paper are solely the responsibility of the authors and do not necessarily represent the official views of the funder. 